\title{
Religious Movement as a Necessity for Early Middle Age 'Heretics' and the Church
}

Stephen Eperjesy

\begin{abstract}
The nature of the 'Christian Middle Ages' in Europe and the interaction of 'heretical groups' operating within France is anything but the simplistic model that we conjure in our minds when we hear the terms 'Christian' Europe and 'heretics'. A juggernaut of power embodied by the Church, bending to nothing and rooting out the poor, unintelligent 'heretics.' This paper will venture to enlighten the reader to the exceedingly complex relationship between the Church and the 'heretical' groups. Furthermore, examining the membership of the 'heretics,' their industries as well as modern contributions from leading historians, will allow the reader to see how the Church undertook a policy of accommodation towards 'heretics' and actively sought to recruit, not necessarily exterminate these heretical groups, in order to invest in the Church itself and strengthen its power base.
\end{abstract}

In order to maintain an appropriate hold on the spiritual world of Christendom, the medieval Church was forced to contend with the 'heretical' practices of many 'Christian' individuals who were dissatisfied with their current lives and actively sought out the apostolic life of early Christianity which promised more fulfillment. These apostolic groups were far more complex in their composition than had ever been previously appreciated and it is only through modern scholarly work that the nature of these individuals is coming to light. Scholars like Herbert Grundmann, Jean Claude Schmitt and James Russell have advanced the field in such a way that the previously theologically dominated subject of the medieval Church has been opened up to investigation by the fields of sociology and anthropology. The results have been the dismissal of the idea of a completely 'Christian' medieval Europe. This opens the possibility to explore the Church as a state with its own particular goals and more importantly how the Church dealt with the constant movement that was necessitated by the rise of 'heretical' groups. ${ }^{1}$

The investigation of movement within 'Christian' Europe - the movement would appear to be inherent not only to the 'true' Christians, for example inquisitors and travelling clerics but also to those 'Christians' deemed heretical- benefits from examination of monographs by Grundmann and Schmitt. As a review of these authors' contributions to the understanding of movement has already been completed by myself in addition to supplementary thoughts would be advantageous to a more in depth analysis of the 'Christian Middle Age' movement.

Grundmann's Religious Movements in the Middle Ages and Schmitt's The Holy Greyhound illustrates two different approaches to viewing medieval Christianity. By attacking the problem of the actual membership of Christianity by investigating the more learned, literate culture and the folktale culture of rural France, respectively. Grundmann is indeed quite broad in his investigation considering many 'heretical' groups, while Schmitt focuses exclusively on an exemplum by Stephen of Bourbon

\footnotetext{
${ }^{1}$ Religious movement in this context refers to an actual physical movement both of the 'heretics' and the Church (which will be explored later on in this paper). Furthermore, 'heretics' is in apostrophe's intentionally as the designation 'heretic' was a term appended to those who were not 'Christian' in the eyes of the Church, by the Church. As this paper will convey later on, there is an inherent problem with the notion of a Christian Middle Ages and as such these subversive groups may still have been practicing what they believed was a form of Christianity.
} 
regarding misguided Christian behaviour in central France. Schmitt's methodology takes a modern approach to the problem of 'movement' within 'Christian Europe.' As John Van Engen thoroughly explains in his article The Christian Middle Ages as an Historiographical Problem, recent scholarship such as Smitt has taken a strong preference for applying sociological and anthropological fundamentals to matters attempting to explain the history of the church. ${ }^{2}$ Grundmann's work is more traditional in its presentation, however, still contributes 'monumentally' to the analysis of Christian Europe in the Middle Ages. ${ }^{3}$

Using a far more educated and predominantly literate base of sources, Grundmann makes the compelling argument that the membership of the many heretical groups was in fact from the wealthy merchant classes or even disaffected, literate clerics. ${ }^{4}$ Furthermore, Grundmann goes so far as to disprove the presence of the lower classes, specifically the peasant class, in the membership of the heretical groups. ${ }^{5}$ Grundmann argues it was the notion of the apostolic lifestyle which appealed so strongly to the burgher class that rejecting the contemporary model of Christian behaviour. This model appeared to be a completely logical (and legitimate) option. What is most pertinent to the notion of the movement is the occupation that heretics undertook in order to sustain themselves after relieving themselves of their worldly possessions. Weaving would have allowed the heretics to remain completely mobile in their operations. Thus, having the universal skill of weaving, these 'heretics' were free to move throughout the land, preaching, but never burdening others with begging. In comparison, Schmitt's peasant farmers of the Dombes region would have had a high degree of investment in their farm properties, and lacked the skills of the mobile weavers, would never have been able to leave their meagre existence in search of apostolic poverty, nor could they spread the ideas of their local, regional cults. ${ }^{6}$ They were already living in a state of subsistence poverty. In a related trend applicable to this model of wealth, mobility and Christianity, Russell explains that many early Christian converts were pagan intellectuals forced into artisan occupations and suffered from 'status dissonance." Subsequently, this feeling of 'status dissonance' would have promoted the seeking out of a group with perceived equal treatment and status, thus satisfying the need for social acceptance. ${ }^{8}$

What is now visible is the Church and the 'heretics' exploited the literal movement of people created during the twelfth century. This exploitation took the form of accommodation on the part of the Church, eventually took the Humiliati into the protection of the Papacy. The Humiliati or 'humble ones,' were first recorded as emerging from between the Alps and Apennines in the 1170's. Andrews argues that the Humiliati were small, ad hoc religious groups comprising of Catholic men and women. ${ }^{9}$ Despite being labelled as heretics in 1184 by Pope Lucius III and Frederick Barbarossa, the Humiliati would eventually gain a very large following by the mid-twelfth century. ${ }^{10}$ Significantly, the Humiliati were one of the self-sufficient 'heretic industry' groups that played an important part in

\footnotetext{
${ }^{2}$ John Van Engen, “The Christian Middle Ages as an Historiographical Problem," The American Historical Review, Vol. 91, No. 3 (Jun., 1986), 534.

${ }^{3}$ Van Engen, 522.

${ }^{4}$ Herbert Grundmann, Religious Movements in The Middle Ages $\mathbf{z}$ (Notre Dame: University of Notre Dame, 1995$), 16$.

${ }^{5}$ Grundmann, 17.

${ }^{6}$ The regional cult in this case being that of Guinefort, the Holy Greyhound.

${ }^{7}$ James Russell, The Germanization of Early Medieval Christianity: A Sociobistorical Approach to Religious Transformation, (Oxford University Press, 1994), 84.

${ }^{8}$ Russell, 84.

${ }^{9}$ Frances Andrews, The Early Humiliati,(Cambridge University Press, 1999), 2.

${ }^{10}$ Andrews, 2.
} 
regional economy and municipal administration. ${ }^{11}$ This has given way to a scholarly movement regarding not just heretics, but also by the Church. The incorporation of a strong economic 'heretic' faction may be of importance when considering the notion of the Church as a 'state.'

The application of sociological interpretations to medieval religion Van Engen argues gives credence to the idea that the Church was truly its own autonomous state with very specific and focused, both regional and international, socioeconomic and political goals. ${ }^{12}$ Furthermore, using Brentano, Van Engen also sees the possible conclusion the "most important figure was not the pope, theologian, or mystic but the proctor, the facilitator of endless routine business."13 Additionally, Van Engen traced the rise of the papacy through sociopolitical and administrative developments through Richards and Sayers. ${ }^{14}$ We could then interpret the accommodation concessions made by the Church as deliberate and carefully considered 'state' decisions. This is further supported by the fact the Humiliati were acting on behalf of the Church in an anti-heresy, quasi mercenary missionary capacity. ${ }^{15}$ The progression Grundmann highlights in his analysis of heretics is mirrored in the Church as well. The Church would maintain a steady momentum of influence by making concessions where it was worthwhile, or attempting to cease erroneous practices such as those found in the Dombes region in Schmitt's The Holy Greyhound. ${ }^{16}$

The idea of Christianity or 'Christendom' as a manner of secular control is considered by Van Engen. With King Edmund in his code, those Christian men in his lands would receive a tithe solely on the grounds of their being a Christian. ${ }^{17}$ Ethelred also starts his law code "...to hold zealously to a single Christianity... to hold to one Christianity under one kingship."18 In effect, Christianitas is intended to be an overarching, common religious property under which united a population, having been baptized, and thus could call themselves 'Christian'. ${ }^{19}$ The main problem facing this notion of the overarching nature of Christianity is whether or not this was indeed the case: was Christianity as pervasive of daily life as was previously expected?

To draw on Van Engen's article once more, we see that due to scholars like Grundmann and Schmitt, the antiquated notion Christianity was completely diffused throughout Europe in the Middle Ages is largely incorrect. To demonstrate the movement towards this point of view, Van Engen chronicles how exactly the notion of a 'Christian Middle Ages' came to be, citing examples from eighteenth century essays reminiscing about formerly 'Christian,' united Europe. The enlightenment, Van Engen argues allowed the learned to rediscover "the spirit and beauty of an ancient order animated in the main, as they saw it, by Catholic Christianity." 20 This concept is important, because the romantic mystique of medieval Europe and Christianity came together during an historically turbulent period and the perceived unity and peace of the time in question became an ideal and goal for those attempting to understand and explain, 'modern,' post-industrial, post-revolutionary Europe. Indeed, it was the 'spiritual bankruptcy' of the period that prompted the

\footnotetext{
${ }^{11}$ Grundmann, 40.

${ }^{12}$ Van Engen, 534.

${ }^{13}$ Van Engen, 534.

${ }^{14}$ Van Engen, 534.

${ }^{15}$ Grundmann, 40 .

${ }^{16}$ Jean-Claude Schmitt, The Holy Greyhound: Guinefort, Healer of Children since the Thirteenth Century (Cambridge: Cambridge University Press, 1983), 23.

${ }^{17}$ Van Engen, 540.

${ }^{18}$ Van Engen, 540.

${ }^{19}$ Van Engen, 540-541.

${ }^{20}$ Van Engen, 520.
} 
nostalgic appreciation of the 'Christian Middle Ages. ${ }^{21}$ Van Engen proceeds to explain the demise of the concept of the 'Christian Medieval Ages' as a movement in the mid 1970's argued that Europeans during the twelfth century, for example, were only marginally or superficially Christianized. Thus, the old view developed in the post-enlightenment era was replaced, Van Engen poses the question which effectively sums the problem facing 'Christian Europe' in the Middle Ages: "Were the Middle Ages then a flourishing epoch of Catholic Christianity or a millennium of IndoEuropean folklore?"22 To Van Engen, the fact such a radical question can be so centrally important to medieval historiography, challenging the authority and established history of both the Church and Europe, demonstrates a critical change in understanding the Middle Ages occurred. ${ }^{23}$ Knowing the notion of a united 'Christian Middle Ages' is a fallacy makes it possible to turn to Russell's treatment of the spread of Christianity to Germanic populations and investigate how movement impacted the missionary efforts.

The very notion of Russell's thesis, the Germanization of Christianity, suggests a movement. As we have seen above, accommodation on behalf of the Church is a manifestation of this movement. According to Russell, it was the accommodation of the Germanic religiocultural attitudes by the Christian missionaries that effectively shifted Christianity into a more folk religion, as it is presented in Schmitt. ${ }^{24}$ Wallace-Hadrill's example regarding the appropriation and appreciation of warfare as a means of spreading Christianity proves to himself and Russell that the cultural movement was from the Christians to the Germans and not vice versa. ${ }^{25}$ As much as the Church had given power to the 'heretics' they similarly gave power to the Germanic people they were attempting to convert. Russell argues that while it may be possible for a folk religion to be supplanted by a universal religion like Christianity, high group solidarity by the folk culture will invariably reverse these changes: ${ }^{26}$ The lack of social disorder or anomie does not create the need of the folk culture to change their wellestablished religious practice. The dissolution of the high solidarity the Roman Empire possessed until roughly the second century would have created significant social distress to make the 'average pagan Roman' begin actively seeking out an alternative to their presently dysfunctional lifestyle. Russell explains

...to fully appreciate the very real disparity between the process of Christianization in classical and Germanic societies, one must recall that each was at a different stage of development when it encountered Christianity. The anomic, heterogeneous, urban stage of a senescent classical civilization must be contrasted with the more cohesive, homogeneous, pastoral-warrior stage of a nascent Germanic culture. ${ }^{27}$

The promise of Christian salvation that would come with membership surely would have been a most suitable replacement for the Roman pantheon. ${ }^{28}$ This period would therefore be typified by the presence of a spiritual movement in the similar fashion as 'heretics' in the twelfth century seeking the apostolic life. In considering the apostolic ideal once more, investigating the motivation

\footnotetext{
${ }^{21}$ Van Engen, 521.

${ }^{22}$ Van Engen, 522.

${ }^{23}$ Van Engen, 522.

24 Russell, 39.

${ }^{25}$ Russell, 40.

${ }^{26}$ Russell, 50.

${ }^{27}$ Russell, 98.

${ }^{28}$ Russell, 97.
} 
of St. Francis of Assisi in his search of an apostolic life can further expose the conditions that 'heretics' experienced.

As was the case with Peter Waldo the founder of the Waldensian movement, Placid Herman details St. Francis as an individual who lived in a world increasingly devoted to the material world rather than the spiritual duties of Christians. ${ }^{29}$ Similar to Waldo, St. Francis rejected the material possessions and devoted his energies to the pursuit of the apostolic life. We can immediately recognize similarities between the story of St. Francis and the historical analysis by Grundmann. Specifically, we learn St. Francis was the son of a wealthy merchant and professed to be a capable salesman, literally selling even the horse he rode in on. ${ }^{30,31}$ St. Francis appeared to be morally heavily burdened by the sum he carried and was anxious to relieve himself of such a burden, a theme shared with Peter Waldo. ${ }^{32}$ Evidence of the Germanization, championed by Russell, is evident in the reference to St. Francis as a soldier of Christ. ${ }^{33}$ It further speaks to the resolve and dedication of these apostolic individuals when considering the immense hardships they willingly undertook. To submit one's body to such self-induced punishments as hurling oneself into a ditch full of ice ultimately displays that the benefits of these practices did in fact outweigh the costs. ${ }^{34}$ That is, to actively punish oneself to such an extent must have been seen as a fundamental part of that individual's belief.

When reading about the live of St. Francis, it is quite evident the notion of movement is ever present. Constantly, St. Francis is moving from place to place, preaching and gaining more adherents. Perhaps most surprising is St. Francis' preaching to animals and apparent control over nature. It was his ability to quiet birds with his delivering of a sermon that allegedly convinced onlookers this individual must be a saint. ${ }^{35}$ Furthermore, Celano tells of two other stories of rabbits and fish that speak to the divine connection to nature of St. Francis and his ability to control the elements. ${ }^{36}$ These attributes of St. Francis would seem to straddle the two different worlds proposed by Russell: world-rejecting and world-accepting religions. As Christianity is a world rejecting religion, we do see St. Francis taking the position of an individual who is undoubtedly moving towards Christianity as a world-accepting religion. The acceptance of the Franciscans by the Church is all the more surprising since this group had not been previously sanctioned against by the Church. More importantly, Grundmann notes that many cardinals, in considering the legitimacy of St. Francis' plans for a brotherhood, were concerned that such a community based on strict apostolic poverty would not be viable. ${ }^{37}$ This again suggests the state-like attitude taken by the Church when considering concessions. Preferring to admit a group that would be ultimately self-sufficient and not drain Church resources. Yet, it should once more be stated the composition of the Franciscans was similar to that of other heretical groups. Seeing membership grow from the admission of: clerics, burghers, nobles, rich merchants and scholars. ${ }^{38}$ Perhaps, with membership so similar to that of the Humiliati, it is not surprising to see the great influence that the Franciscan order weld in the future.

\footnotetext{
29 Thomas of Celano, Saint Francis of Assisi (University of Alberta Edition), (Franciscan Press: 2009), 1.

${ }^{30}$ Grundmann, 14.

${ }^{31}$ Celano, 48.

${ }^{32}$ Celano, 48.

${ }^{33}$ Celano, 48.

${ }^{34}$ Celano, 76.

${ }^{35}$ Celano, 91.

${ }^{36}$ Celano, 92.

${ }^{37}$ Grundmann, 57.

${ }^{38}$ Grundmann, 73.
} 
Van Engen argued when it came to medieval folk movements, there was still a perceived necessity to continue reinventing Christianity in light of other religious practices within Christianity. ${ }^{39}$ Furthermore, Van Engen notes "Medieval folk understood well enough that they did not live in a golden age of Christian religious life, though they constantly invoked Christian norms and practices as the ideal toward which they strove. ${ }^{40}$ What Van Engen stressed to scholars is that there was an intrinsic characteristic of Christianity that saw the façade of their 'modern' Christianity. That is, the reinvention of Christianity in the form of heretical groups was actually a natural progression within the framework of 'Christendom' and their seeking out of the apostolic lifestyle was simply an expression of nostalgia. This idea is reflected in one of the causes for the revival of scholastic work on the 'Christian Middle Ages'. The 'spiritually bankrupt' look back on the past 'ideal' Christianity and actively sought it out once more. ${ }^{41}$

Europe during the medieval period was indeed a complex composition of many different adherents to multiple variations of Christianity. Thus, the notion of a united, complete Christian Europe has largely fell by the wayside in favour for considering the region during this period as a religiously fragmented and largely folk culture. In order to maintain the influence that it had grown accustomed to, the Church was forced to mimic the plastic nature of what was to be considered correct Christian beliefs by the masses. Specifically, the movement so highly characteristic of the heretics was to be adopted through acts of accommodation by the Church. Through examining Schmitt and Grundmann, we witness two different explanations for the composition of the heretical groups and also the nature of Christianity as a religion populated by many different groups with different perceptions on what exactly Christianity should be. It is of central importance to the concept of constant movement within the Church to understand that membership of heretical groups would eventually fall under the protection of the Papacy. It is here, with Grundmann that an analysis heavily dependent on primary sources emerges and we see the composition of heretical groups being nearly exclusively to burgher, merchant or clerical backgrounds. More importantly, Grundmann identified the preferred occupation of the 'heretics' as that of weaving. This bears great significance to the idea of movements within Christianity as these wanderers were part of a highly mobile group, self-sufficient in not begging for alms and able to create an influential 'heretic industry.' Using the example of the Humiliati, this heretic industry would eventually become very influential in administrative functions. It is through understanding the composition and the literal ability of the 'heretics' to move themselves and their ideas that we may gain insight into exactly what Grundmann meant in his usage of the phrase 'religious movement', a phrase Van Engen claims Grundmann never qualified with a definition. ${ }^{42}$

Van Engen in his article "The Christian Middle Ages as an Historiographical Problem" focuses heavily on how scholarship regarding the religiosity of medieval Europe has taken a significant shift towards incorporating sociological and anthropological models. Through the usage of these models it is possible to view the Church not solely as a religious institution, but also as a 'state' with its own political and socioeconomic goals. Van Engen qualifies this notion by using simoniac practices to enter monastic life as a prime example of how members of the church would use their influence to achieve certain socioeconomic and political goals. The Church was, by making concessions to the heretical groups, constantly in a state of movement. The life of St. Francis provides excellent evidence towards furthering the idea that both the 'heretics' and the Church were in a state of

\footnotetext{
${ }^{39}$ Van Engen, 537.

${ }^{40}$ Van Engen, 538.

${ }^{41}$ Van Engen, 520.

${ }^{42}$ Van Engen, 524.
} 
constant movement. Grundmann's argument regarding the composition of 'heretics' is qualified in the fact that St. Francis comes from and was indeed part of the wealthy merchant class. The behaviour of St. Francis in regards to his straddling of both the world-rejecting and world-accepting ultimately displays a system of beliefs not completely uniform with those doctrines of the Church. However, these beliefs were eventually accepted by the Papacy despite having no previous relations, as many other 'heretical' groups did. ${ }^{43}$

It is through the culmination of this evidence that we begin to see how the phrase 'religious movement' can be considered a literal movement spiritually, physically and socio-politically. The heretical groups and the Church were in a constant state of change, playing off one another and as a result advancing each other. The Church, to remain a viable source of temporal and spiritual power, was obligated to remain mobile and plastic in its operations less it totally fail to provide the spiritual guidance and authority that was, for centuries, required of it.

${ }^{43}$ I.e. The Waldensians and Humiliati. 


\section{Bibliography}

Andrews, Frances. The Early Humiliati. Cambridge: Cambridge University Press. 1999.

Grundmann, Herbert. Religious Movements in the Middle Ages. Notre Dame: University of Notre Dame. 1995.

Russell, James. The Germanization of Early Medieval Christianity: A Sociohistorical Approach to Religious Transformation New York: Oxford University Press. 1994.

Schmitt, Jean-Claude. The Holy Greyhound: Guinefort, Healer of Children since the Thirteenth Century. Cambridge: Cambridge University Press. 1983.

Thomas of Celano. Saint Francis of Assisi (University of Alberta Edition). Winona: Franciscan Press. 2009.

Van Engen, John. "The Christian Middle Ages as an Historiographical Problem." The American Historical Review 91, No. 3 (June 1986). 